\title{
Externalization at work: responses to migration policies from the Global South
}

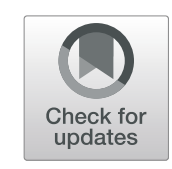

Inka Stock ${ }^{1 *}$, Ayşen Üstübici ${ }^{2}$ and Susanne U. Schultz ${ }^{1}$

\author{
* Correspondence: inka.stock@uni- \\ bielefeld.de \\ ${ }^{1}$ Bielefeld University, Bielefeld, \\ Germany \\ Full list of author information is \\ available at the end of the article
}

\begin{abstract}
The term "externalization" is used by a range of migration scholars, policy makers and the media to describe the extension of border and migration controls beyond the so-called 'migrant receiving nations' in the Global North and into neighboring countries or sending states in the Global South. It refers to a wide range of practices from controls of borders, rescue operations, to measures addressing the drivers of migration. The ambition of this Special Issue is to contribute to the mapping of the responses to externalization dynamics. The different articles in this volume are chosen to exemplify some of these processes at different levels of analysis. Through diverse disciplinary perspectives, the authors show how practices of externalization are being confronted, succumbed, modified and contested by individual (would-be) migrants, civil society actors and the host states' institutions in different parts of the globe. In an effort to move away from a sole focus on border zones in the Global North, the Special Issue contributes to emerging literature shifting the locus of analysis to places in the Global South, which are conventionally understood as "transit" or "sending" countries in Africa, America as well as within Europe itself.
\end{abstract}

Keywords: Externalization, Global South, Global North, Migration, Migration governance, Social mechanisms

\section{Introduction}

In January 2019, Behrouz Boochani's book "No Friend but the Mountains" received the prestigious Victorian premier's literary award in Australia. Boochani is a Kurdish journalist from Iran, who, after an unsuccessful attempt to claim asylum in Australia, was detained in the Manus Island, in Papua New Guinea. He had been stranded on the island for almost 6 years, waiting for his asylum claims to be recognized by the Australian authorities. He wrote his book by sending text messages via his phone to his translator in Australia. Behrouz Boochani was not even granted entry to Australia to attend the award ceremony (Wahlquist, 2019). Boochani's story has been widely publicized by the media and in activist circles. It brought public attention to the way inhumane border and migration policies impact peoples' lives. In this context, the term 'externalization' was invoked to describe the extension of border and migration controls from the so-called migrant receiving nations in the Global North and into neighbouring countries or sending nations in the Global South (Frelick, Kysel, \& Podkul, 2016; Kipp \& Koch, 2018; Lavenex, 2016; Menjivar, 2014).

(C) The Author(s). 2019 Open Access This article is distributed under the terms of the Creative Commons Attribution 4.0 International License (http://creativecommons.org/licenses/by/4.0/), which permits unrestricted use, distribution, and reproduction in any medium, provided you give appropriate credit to the original author(s) and the source, provide a link to the Creative Commons license, and indicate if changes were made. 
In public debates, justifications for externalization measures in international migration policies are often framed in cost-efficiency terms. Here, migration management appears to bear resemblance with outsourcing strategies in financial transactions, where costs are transferred to third parties in order to increase profit margins. This is particularly evident when politicians in the Global North suggest that the political, social and economic costs of migration should be effectively transferred to third parties, generally located far away from the country of final destination. This kind of economic logic in migration management frames migrants primarily as a burden for receiving countries, rather than as part of positive social change in both sending and receiving societies (Castles, 2010). However, this kind of "externalization-talk" also provides a political justification for the transfer of moral responsibility for migrants' well-being from states in destination countries to actors on the national or local levels in origin countries or transit spaces.

Beyond externalization's use as a mere policy tool to reduce the economic, political and social costs of 'unwanted immigration' for receiving states, it is possible to use externalization as a heuristic devise to investigate the effects and processes of increasingly globalised migration policies. In order to move in this direction, we conceptualise externalization policies and practices as constitutive of a set of social mechanisms, which are responsible for the reproduction and changing shape of social, economic and political border making processes in transnational spaces (Faist, 2009). In particular, we want to show through the empirical cases presented in this Special Issue that externalization measures can be understood as processes which produce and reinforce relations of inequality in the management of mobility between states, states and civil society organisation, and migrants (Diewald \& Faist, 2011; Faist, 2018).

One of the difficulties in studying externalization lies in the great diversity of practices, discourses or policy measures that have been identified as its essential parts. Research has shown, for example, that externalization policies do not only include the outsourcing of border controls to third countries, through visa procedures, readmission agreements or border checks. Instead, it is increasingly important to consider that externalization measures also imply those policy initiatives which are geared to support "migration management" in third countries. These policy initiatives potentially result in immobilising would-be migrants in their countries of origin or along the way in so called transit-countries, and "select" and "filter" those migrants deemed adequate for further mobility (Frelick et al., 2016). Furthermore, research on externalization needs not only to focus on what is externalised and how it is done, but also to which actors' responsibilities of border control and migration management are transferred. Today, externalization measures are no longer limited to state-state relations but involve increasingly the subcontracting of private and civil society organisations. For example, airlines and other transport companies undertake passport and visa checks (Gammeltoft-Hansen, 2011). Further, economic development programmes financed by the EU with the aim to combat the root causes of migration, are often linked to aspects of controlling migration alike, but implemented by local non-governmental organisations.

A second challenge concerns locating where the effects of externalization policies are felt and how they shape socio-economic and political realities in these places. While it is assumed that externalization practices are happening at borders, it has appeared difficult to theorize where borders start. Scholars have come up with terms such as borderlands (Brambilla, 2010), border zones (Gaibazzi, Bellagamba, \& Dünnwald, 2017) 
or the "differential inclusion/exclusion" of borders (Casas-Cortes, Cobarrubias, \& Pickles, 2015, p. 907) trying to capture such complexity. In some contexts, the effects unfold at different levels, which render inside/ outside distinctions of borders and classifications of actors and institutions involved in bordering practices difficult to uphold. In other words, as borders are expanding through externalization practices both outwards and inwards at the same time (Hansen \& Papademetriou, 2014), it is difficult to distinguish between externalization as such and internalization of the mechanisms of externalization (cf. Faist, 2019, in this issue).

With the articles in this Special Issue, we contribute to advance theoretical thinking about these complex dynamics with empirical evidence from different locations and levels of analysis. In the first part of this introduction, we will refer to the theoretical approach of social mechanisms to demonstrate how externalization processes can be characterised by a set of similar practices and beliefs, which gives rise to diverse yet comparable outcomes across different regions of the world (Faist, 2018). In the second part, we will focus on how to study the responses to externalization from an interdisciplinary perspective, while in the last part, we present the content of the articles in this Special Issue.

\section{Externalization as a social mechanism}

In academia, externalization policies and practices have been contextualised, in part, as a reaction to a more general shift in contemporary international politics whereby certain types of mobility have been conceptualised as a security threat to the nation-state (Bruns, Happ, \& Zirchner, 2016; De Genova \& Peutz, 2010). Research has shown that during the last decade, there has been an increased tendency in certain countries and regions of immigration, such as the EU, the US and Australia, to transfer and diversify border control and migration management mechanisms not only to neighbouring socalled 'transit' countries with the aim to diminish migration and refugee flows, but also to more distant countries in Africa, Asia, the Middle East and Central America. These efforts are increasingly coupled with the instrumentalisation of development assistance such as EU development aid for migration policy making in line with the donors' interests (Geiger \& Pècoud, 2012; Kipp \& Koch, 2018; Korf \& Raeymaekers, 2013). Available literature thus shows that there are similar patterns across regions with regards to the deployment of externalization procedures.

In our view, migration management through externalization is best conceptualised as a set of policies and practices generative of specific social mechanisms. The term (social) mechanism refers to recurrent processes or pathways, linking specified initial conditions (not necessarily causes in the strict sense) and specific outcomes, the latter of which can be effects produced or purposes achieved. Social mechanisms can therefore be defined as "a delimited class of events that alter relations among specified sets of elements in identical or closely similar ways over a variety of situations" (McAdam, Tarrow, \& Tilly, 2001, p. 24). In line with this approach, we are framing externalization processes as composed of a set of specific actors, regulations, practices and discourses involved in migration management, which in conjunction produce similar effects on mobility and settlement dynamics in different contexts. These effects range from the individual to macro structural levels. By adopting this framework, we assume that the externalization of migration measures, which are discussed in the empirical case studies 
in this Special Issue share certain principles. These make them and their differentiated effects comparable across the varying transnational social spaces in which they operate.

\section{Effects of externalization}

Externalization policies are representative of larger social, cultural and economic boundary-making processes in transnational spaces (Faist, 2009). These boundarymaking processes are contributing to the production and reproduction of inequalities between countries, institutions and people because they reinforce particular stereotypical perceptions about migrants and mobility and cement affiliations between particular actors on the expense of the exclusion of others. They thus validate asymmetric relationships between states and social hierarchies between actors, institutions and rules, with the aim to produce social closure or the hoarding of opportunities for some on the expense of others (Faist, 2018). Externalization polices may therefore be meaningfully conceptualised as specific types of social relations in which opportunity stockpiling and social closure are sought at least by one party in the relationship in order to accumulate power over the other (Faist, 2018, p. 16). In most cases, measures of externalization result in the circumvention of basic norms, go against good governance, create immobility and contribute to the crisis of the global refugee regime, which fails to provide protection (Betts \& Collier, 2017).

These relations of inequality produce geographies of control as well as spaces of resistance, changing the lives and migration trajectories of migrants and their families. We know, for instance, the externalization of border policies is contributing not only to selective mobility, but also to growing numbers of migrants and wouldbe migrants who are being forcibly immobilised during or even before their migratory project (Carling, 2002; Collyer, 2007; Stock, 2019). There is evidence to suggest that externalization policies also influence social, political and economic institutions and practices in so-called 'transit' and 'sending' states. In sum, there are varied and serious consequences of, and reactions to externalization policies which go far beyond migration management, but are often overlooked in academic debates when migration policy and practice is analysed solely through a state-centric view of governance and institutions (Casas-Cortes et al., 2015; Lavenex, 2016). Furthermore, externalization policies are also contested and changed at local levels by actors and institutions "from below". In this vein, states in so called 'transit' or 'sending' nations are appropriating particular discourses for their own regards to migrant management. Similarly, there are NGOs and migrant networks constructing veritable rescue industries on the basis of the increasing restrictions to movement and the filtering policies of those with possibilities to be mobile and those who are not (Andersson, 2014). Equally, migrants themselves are adapting (im) mobility strategies by taking control of alternative regulatory frameworks to the state, such as market-based or family networks, in order to foster mobility options (Alpes, 2017). In this sense, externalization of migration management can be thought of as a battlefield, in which different actors are positioning themselves in order to gain access and control over mobility and resources, settlement and its governance. Meanwhile they are renegotiating social, legal and institutional 
boundaries of (im) mobility and citizenship in different ways. In these battles, it is not always the traditional destination states in the Global North who are succeeding eventually in accumulating power over (im)mobility.

\section{How to study externalization(s)}

While there are attempts to systematise and theorize the functioning of the measures of externalization (Kipp \& Koch, 2018; Moreno-Lax \& Lemberg-Pedersen, 2019), more research is needed to conceptualize the responses from the South that externalization mechanisms generate. In other words, we need to understand better how these struggles work, which contestations are particularly successful in disrupting and confronting social inequality, and also, which inequalities are effectively reproduced.

Existing literature on the externalization of migration policies and border controls predominantly represents the view from border spaces of traditional immigration countries in the 'developed North', focusing here mostly on the interrelation between control and rescue mechanisms (Pallister-Wilkins, 2015). While policy discussions often centre on the success of such policies, they are neglecting a deeper analysis of the workings of externalization policies in 'transit' and 'sending' countries. For that reason also, the term is rarely used in academic debates outside the Northern Hemisphere (cf. Gaibazzi et al., 2017, p. 10). In an effort to fill this gap, this Special Issue aims to document and theorize the responses to externalization policies and practices primarily from the perspective of those who are concerned by it in 'sending', and 'transit' countries in Africa, Europe, and the Americas. Furthermore, contributions will highlight regional similarities and differences in terms of the repercussions of externalization processes on migrants, civil society and state institutions (Üstübici, 2018). Thus, the articles in the Special Issue will address the consequences of, and reactions to externalization policies, particularly focusing on the economic, social and political implications for different actors involved in the process of externalization.

This task can be undertaken from multiple disciplinary perspectives including, but not limited, to political, geographical, sociological and anthropological approaches. In international relations, for example, researchers have looked at how states in the Global South are using externalization policies as a political tool to engage in practices of brokerage over international protection measures (İçduygu \& Üstübici, 2014). Such perspectives can show how externalization affects the conversion of domestic into foreign policies and vice versa. From a geographical perspective, externalization practices can be studied by investigating their influence on mobility routes, migration systems and directions of migration (Shapendonk, 2011). Externalization processes may also alter societal relations between migrants and citizens and impact on cultural practices, values and community relations in origin, transit and destination countries, on which sociologists and anthropologists focus (Stock, 2019; Suter, 2012; Üstübici, 2016). The articles in this Special Issue further provide empirical evidence from different perspectives on how mechanisms and actors of externalization interact to construct particular spaces of governance and contestations on different levels of analysis. Such an interdisciplinary approach contributes to a better understanding of how inequality is produced, reproduced and contested in the context of externalization measures.

By concentrating particularly on the effects of and the reactions to migration control policies in countries of the Global South, we also tackle the issue of methodological nationalism (Faist, 2015; Wimmer \& Glick Schiller, 2003), which often makes us overlook the 
connections between sending, transit and receiving societies of migration, as well as between migrants and the people and organizations in their transnational networks - many of them within the Global South. By doing this, we can bring to the surface and draw comparisons on how seemingly very similar migration governance structures and rationales operate between EU-Turkey, EU-Africa and North-South America with their spill over effects in wider geographies, yet manifest themselves in diverse local realities and contestations.

\section{Content of this special issue}

This Special Issue is composed of seven empirical papers and concluding remarks. The collection of articles brings together young scholars of international relations, political science, sociology and anthropology either based in or working on the Global South, in inter-disciplinary dialogue around this multifaceted phenomenon. Our theoretical stance is inspired but not limited to critical border and migration studies, critical security studies, socio-legal studies, sociology and anthropology. The contributions cover externalization policies and responses to them in countries bordering the European Union, such as Moldova, Morocco and Turkey, but also further afar, such as in Mali. We are also looking at the reactions to EU and USA externalization policies in Argentina and Costa Rica by focusing on African migrations to these countries. Underlying our analysis of the responses to externalization policies and practices is the acknowledgement of unequal power relations between the Global North and the Global South and their impact on migratory dynamics. Each article acknowledges and reveals the power relations between the actors involved in implementation practices and the different forms of manifestations of agency and resistance under these conditions.

Articles are arranged based on their level of analysis of externalization policies and practices, mainly from a broader country level analysis towards a focus on the meso and micro levels. The empirical data help us to deconstruct some of the prevalent frames of reference, which underlie justifications for externalization policies and the contradictions they generate in practice. The articles exemplify how the policy tools of externalization at the state and the supranational level do not only concern the extension of border control to neighbouring countries but also imply the re-shaping of structural inequalities between North and South, as well as social boundaries in destination and so-called 'transit' countries.

In this regard, Lena Laube's (2019) contribution takes a comparative approach to challenging widely held perceptions of migration governance, in which receiving countries in the North are thought to dominate the externalization of border policy making by imposing their migration policy interest onto 'transit' and 'sending' countries. Focusing on the negotiated aspect of external border controls in the case of visa regulations, she shows how Turkey, Moldova and Morocco are each using different strategies to respond to EU externalization efforts regarding third country nationals by enhancing their opportunities for increased mobility of their own citizens. In the following paper, Aysen Üstübici's (2019) contribution focuses on the macro-institutional level by looking on the socio-legal implications of externalization in Turkey's migration policies. Her analysis reveals how the Turkish state is adapting the rhetoric employed by externalization policies, according to its own interests of social closure and how this process has led to the creation of differentiated legal status among migrants and asylum seekers. Sibel Karadağ's (2019) contribution looks at the informalised and improvised nature of bordering practices along the 
Turkey-Greece border. She shows how coast guards are effectively appropriating and challenging the discourse on externalization of borders in order to recreate social boundaries between Turkey and the EU, which in turn validate Turkey as the active part in this unequal relationship between countries. Nanneke Winters and Cynthia Mora Izaguirre (2019) focus on a state-run migrant shelter in a Costa Rican border town to illustrate the country's ambiguous position in the Central American borderland. They show how the interplay of humanitarian and securitized discourses, policies and practices enacted in the shelter enable African migrants to move further north across hostile terrain.

On the micro-level of social relations, Sylla Almamy and Susanne Schultz (2019) are describing the economic and socio-psychological implications of externalization policies through the eyes of young Malian deportees, would-be migrants and their communities facing migrants' death in the Mediterranean. They show how these are using rituals to commemorate the castaways and eventually contest the dominant Malian state discourses, which devalue irregular migrants by conveying their symbolic connections and alliances to migrant communities in the transnational space. Ida Vammen (2019) and Elsa Tyszler's (2019) contributions both show how migrants negotiate the restrictions to mobility, which are put up through externalization policies by creating new routes, allegiances and strategies in order to stay mobile. Vammen's and Tyszler's articles on young Senegalese migrants in Argentina and on African migrant women in Morocco show how externalization has affected migrants' migration trajectories and makes their journeys increasingly more difficult and dangerous. Vammen discusses how migrants' negotiate their ways despite these constraints by making a variety of alternative regulative authorities work for them. Tyszler is looking at how externalization policies are reinforcing gendered and racialised inequalities among migrants in Morocco. Her contribution reveals that externalization has increased the vulnerabilities and unequal power relations that women are exposed to during their migratory project and how these play out in forced immobility. The Concluding Remarks by Thomas Faist (2019) provide a theoretical and historical outlook that draws attention to the larger context of externalization policies as a way to circumvent the "liberal paradox". He describes the development of externalization from non-entry policies towards the EU being directly involved in the construction of a "cordon sanitaire" in the Global South. In reference to empirical findings in the contributions of the Special Issue, Faist shows how externalization of migration controls made the interplay between border control and humanitarian intervention more ubiquitous. The concluding remarks explore various forms of resistance to such practices but also by showing the limits to attempts aimed at de-territoralising human rights. Hence, Faist invites us to scrutinize and develop alternative conceptualizations of borders, rights and global inequalities when we think about and work on externalization practices and responses to it.

\footnotetext{
Acknowledgments

The authors would like to thank to anonymous reviewers, to Deniz Sert as the editor in chief and to the contributing authors of this Special Issue. The authors are grateful to Bielefeld Graduate School of History and Sociology (BGHS) for hosting the workshop "Beyond External Borders: Multi-level analysis and comparative perspectives on migration governance" convened on 16/17 March 2017. Ayşen Üstübici thanks the IPC Mercator Fellowship programme at SWP Berlin for providing the physical environment during the editing phases of this volume. We specially thank Prof. Thomas Faist for his encouragement and insight since we first seed the ideas for this volume.
}

Authors' contributions

This study was designed and directed by the authors IS, AÜ, SUS. All authors read and approved the final manuscript.

Funding

Not applicable. 
Availability of data and materials

Not applicable.

Ethics approval and consent to participate

Not applicable.

Consent for publication

Not applicable.

Competing interests

The authors declare that they have no competing interests.

\section{Author details}

'Bielefeld University, Bielefeld, Germany. ${ }^{2}$ Koç University, Istanbul, Turkey.

Received: 23 July 2019 Accepted: 16 September 2019

Published online: 17 December 2019

\section{References}

Alpes, M. J. (2017). Brokering high risk migration and illegality in West Africa: Abroad at any cost. Abingdon and New York: Routledge.

Andersson, R. (2014). Illegality. Inc. Berkeley: University of California Press.

Betts, A., Collier, P. (2017). Refuge: Transforming a broken refugee system. Penguin UK.

Brambilla, C. (2010). New approach in border studies: The need for re-thinking the European-African borderland through the case of the EU-SADC relationship and the Caprivi strip. Journal of Borderlands Studies, 23(3), 55-68.

Bruns, B., Happ, D., \& Zirchner, H. (Eds.). (2016). European Neighbourhood policy: Geopolitics between integration and security. Basingstoke: Palgrave Macmillan.

Carling, J. (2002). Migration in the age of involuntary immobility. Journal of Ethnic and Migration Studies, 28(1), 5-42.

Casas-Cortes, M., Cobarrubias, S., \& Pickles, J. (2015). Riding routes and itinerant borders: Autonomy of migration and border externalisation. Antipode, 47(4), 894-914.

Castles, S. (2010). Understanding global migration: A social transformation perspective. Journal of Ethnic and Migration Studies, $36(10), 1565-1586$.

Collyer, M. (2007). In-between places: Trans-Saharan transit migrants in Morocco and the fragmented journey to Europe. Antipode, 39(4), 699-690.

De Genova, N., \& Peutz, N. (Eds.) (2010). The deportation regime: Sovereignty, space, and the freedom of movement. Durham: Duke University Press.

Diewald, M., \& Faist, T. (2011). From Heterogeneities to Inequalities: Looking at Social Mechanisms as an Explanatory Approach to the Generation of Social Inequalities (SFB882 Working Paper Series 1). DFG Research Center. Retrieved from https://pub. uni-bielefeld.de/download/2490155/2490156.

Faist, T. (2009). Making and remaking the transnational: Of boundaries, social spaces and social mechanisms. SpectrumJournal of Global Studies, 1(2), 66-88.

Faist, T. (2015). Making and remaking the transnational: Of boundaries, social spaces and social mechanisms (COMCAD Working Papers 132). Bielefeld University URN: Retrieved from http://nbn-resolving.de/urn:Nbn:de:0168-ssoar-50817-9.

Faist, T. (2018). The Transnationalized social question. Oxford: Oxford University Press.

Faist, T. (2019). Contested externalisation: responses to global inequalities (afterword). Comparative Migration Studies, 7. https://doi.org/10.1186/s40878-019-0158-y.

Frelick, B., Kysel, I. M., \& Podkul, J. (2016). The impact of externalization of migration controls on the rights of asylum seekers and other migrants. Journal on Migration \& Human Security, 4(4), 190-220.

Gaibazzi, P., Bellagamba, A., \& Dünnwald, S. (Eds.) (2017). EurAfrican Borders and Migration Management. Political Cultures, Contested Spaces, and Ordinary Lives. New York: Palgrave Macmillan.

Gammeltoft-Hansen, T. (2011). Access to Asylum International Refugee Law and the Globalisation of Migration Control. Cambridge Studies in International and Comparative Law (77). New York. Cambridge University Press..

Geiger, M., \& Pècoud, A. (Eds.) (2012). The politics of international migration management. Basingstoke: Palgrave Macmillan.

Hansen, R., \& Papademetriou, D. G. (2014). Securing Borders-the intended, unintended and perverse consequences. Migration Policy Institute: Washington D.C.

Içduygu, A., \& Üstübici, A. (2014). Negotiating mobility, debating borders: Migration diplomacy in Turkey-EU relations. In H. Schwenken, \& S. Ruß-Sattar (Eds), New Border and Citizenship Politics, (pp. 44-59). Migration, Diasporas and Citizenship Series. Palgrave Macmillan, London.

Karadağ, S. (2019). Extraterritoriality of European borders to Turkey: an implementation perspective of counteractive strategies. Comparative Migration Studies, 7. https://doi.org/10.1186/s40878-019-0113-y.

Kipp, D., \& Koch, A. (2018). Auf der Suche nach externen Lösungen Instrumente, Akteure und Strategien der migrationspolitischen Kooperation Europas mit afrikanischen Staaten [Looking for External Solutions: Instruments, Actors, and Strategies for European Migration Cooperation with African Countries]. In A. Koch, A. Weber, \& I. Werenfels (Eds.), Migrationsprofiteure? Autoritäre Staaten in Afrika und das europäische Migrationsmanagement [Profiteers of Migration? Authoritarian States in Africa and European Migration Management] (SWP-Studie 3). Berlin: Stiftung Wissenschaft und Politik, Deutsches Institut für Internationale Politik und Sicherheit. Retrieved from https:/www.borderline-europe.de/sites/default/files/background/ Migrationsprofiteure\%20SWP.pdf.

Korf, B., \& Raeymaekers, T. (2013). Violence on the margins: States, conflict and borderlands. New York: Palgrave Macmillan.

Laube, L. (2019). The relational dimension of externalizing border control: selective visa policies in migration and border diplomacy. Comparative Migration Studies, 7. https://doi.org/10.1186/s40878-019-0130-x. 
Lavenex, S. (2016). Multilevelling EU external governance: The role of international organisations in the diffusion of EU migration policies. Journal of Ethnic and Migration Studies, 42(4), 554-570.

McAdam, D., Tarrow, S., \& Tilly, C. (2001). The dynamics of contention. New York: Cambridge University Press.

Menjivar, L. (2014). Immigration law beyond borders: Externalizing and internalizing border controls in an era of securitization. Annual Review of Law and Social Science, 10, 353-369.

Moreno-Lax, V., \& Lemberg-Pedersen, M. (2019). Border-induced displacement: The ethical and legal implications of distancecreation through externalization. Questions of International Law, 56, 5-33.

Pallister-Wilkins, P. (2015). The humanitarian politics of European border policing: Frontex and border police in Evros. International Political Sociology, 9(1), 53-69.

Shapendonk, J. (2011). Turbulent trayectories: Sub-Saharan African migrants heading North. (Unpublished doctoral dissertation). Nijmegen, Radboud University. Retrieved from https://repository.ubn.ru.nl/handle/2066/91326.

Stock, I. (2019). Time, migration and forced immobility. Sub-Saharan African Migrants in Morocco. Bristol: Bristol University Press.

Suter, B. (2012). Tales of transit: Sub-Saharan African migrants' experiences in Istanbul (Unpublished doctoral dissertation). Sweden: Malmö University. Retrieved from http://muep.mau.se/handle/2043/14497.

Sylla, A., \& Schultz, S.U. (2019). Commemorating the deadly other side of externalized borders through "migrant-martyrs", sacrifices and politizations of (irregular) migration on the international migrants' day in Mali. Comparative Migration Studies, 7. https://doi.org/10.1186/s40878-019-0167-x.

Tyszler, E. (2019). From controlling mobilities to control over women's bodies: gendered effects of EU border externalization in Morocco. Comparative Migration Studies, 7. https://doi.org/10.1186/s40878-019-0128-4.

Üstübici, A. (2016). Political activism between journey and settlement: Irregular migrant mobilisation in Morocco. Geopolitics, 21(2), 303-324.

Üstübici, A. (2018). The governance of international migration: Irregular Migrants' access to right to stay in Turkey and Morocco. Amsterdam: University of Amsterdam Press.

Üstübici, A. (2019). The impact of externalized migration governance on Turkey: Technocratic migration governance and the production of differentiated legal status. Comparative Migration Studies, 7. https://doi.org/10.1186/s40878-019-0159-x.

Vammen, I.M.S. (2019). New contested borderlands: Senegalese migrants en route to Argentina. Comparative Migration Studies, 7. https://doi.org/10.1186/s40878-018-0109-z.

Wahlquist, C. (2019, January 31). Behrouz Boochani: detained asylum seeker wins Australia's richest literary prize. The Guardian. Retrieved from https://www.theguardian.com/world/2019/jan/31/behrouz-boochani-asylum-seeker-manusisland-detained-wins-victorian-literary-prize-australias-richest.

Wimmer, A., \& Glick Schiller, N. (2003). Methodological nationalism, the social sciences, and the study of migration: An essay in historical epistemology. International Migration Review, 37(3), 576-610.

Winters, N., \& Mora Izaguirre, C. (2019). Es cosa suya: entanglements of border externalization and African transit migration in northern Costa Rica. Comparative Migration Studies, 7. https://doi.org/10.1186/s40878-019-0131-9.

\section{Publisher's Note}

Springer Nature remains neutral with regard to jurisdictional claims in published maps and institutional affiliations.

\section{Submit your manuscript to a SpringerOpen ${ }^{\circ}$ journal and benefit from:}

- Convenient online submission

- Rigorous peer review

Open access: articles freely available online

- High visibility within the field

- Retaining the copyright to your article

Submit your next manuscript at $\boldsymbol{\nabla}$ springeropen.com 